3-15-1994

\title{
Maryland's First Evidence Code
}

Lynn McLain

University of Baltimore, lmclain@ubalt.edu

Follow this and additional works at: http://scholarworks.law.ubalt.edu/all_fac

Part of the Evidence Commons

\section{Recommended Citation}

Lynn McLain, Maryland's First Evidence Code, (1994).

Available at: http://scholarworks.law.ubalt.edu/all_fac/929

This Article is brought to you for free and open access by the Faculty Scholarship at ScholarWorks@University of Baltimore School of Law. It has been accepted for inclusion in All Faculty Scholarship by an authorized administrator of ScholarWorks@University of Baltimore School of Law. For more information, please contact snolan@ubalt.edu. 


\title{
A.M. LAW SERIES
}

March 15, 1994

\section{MARYLAND'S FIRST EVIDENCE CODE}

\author{
Remarks by Lynn McLain, Professor \\ University of Baltimore School of Law
}

I. Effective date of Title 5: July 1, 1994

A. The Rules will apply in all trials and hearings commenced on or after July 1, 1994.

B. Excepuion: in a criminal action regarding a crime allegedly committed before July 1, 1994, no evidence will be admissible against an accused, unless it also would have been admissible under the pre-Title 5 law.

C. Rules reported in January 7, 1994, Maryland Register, pp. T-1 et seq.; January 21, 1994, Maryland Advance Sheet, pp. xi-xev (before 333 Md. 2); and 1994 volume of Md. Rules.

II. History of Title 5 of the Maryland Rules

A. Federal Rules of Evidence, effective July 1, 1975.

B. Uniform Rules of Evidence of 1974.

C. The Rodowsky Committee Report (1977).

D. Charge to the Rules Committee (1988).

E. General folloxing of organization and numbering of federal rules.

F. Adoption of Title 5 by the Court of Appeals, with its amendments: 38th state to adopt a code of evidence derived from the federal rules.

G. Note: Tirle 5 does not address privileges: the common law and (over 200) statutes will continue to govern the law of privilege.

III. A four-minute mile through Title 5: 


\section{Chapter 100-General Provisions}

General applicability of the Rules in all actions and proceedings in Maryland state cours, with two classes of exceptions: proceedings to which Title 5, the Rules of Evidence (except those pertaining to competency of witnesses; privileges also remain applicable, but no reference here is necessary, because rules of privilege are nor found in Title 5), either will be (1) inapplicable (e.g., small claims actions); or (2) applicable, but the court may, in its discretion and in the interest of justice, decline to require stric application of them (e.g., court's determination of preliminary facts under Rule 5-104(2)). (See also conforming amendments to related Rules.)

Intended to be consistent with current practice, except that the Rules clearly apply in plenary proceediogs in the Orphans' Court:

General purposes of the Rules of Evidence - fairness, efficiency, truth and justice: consistent with current Maryland law.

Objections, rulings, and offers of proof: consistent with current Maryland law. Statement of specific ground for objection generally not required, unless requested by court.

Proof of preliminary facts on which questions of admissibility of evidence hinge: consistent with current Maryland law.

Special provision regarding question of voluntariness of confession if, at a suppression hearing, the judge has ruled an accused's confession to be voluntary, and the accused subsequently takes a "second bite at the apple" and testifies at trial before the trier of fact that the confession was involuntary, the accused will be subject to wide-open cross examination. That trial testimony will not be considered to be testimony on a "preliminary matter of admissibility."

\section{LIMITED ADMISSIBILITY}

Limiting instructions on request: consistent with current Maryland law. 


\section{REMAINDER OF OR RELATED WRITINGS OF RECORDED STATEMENTS}

Under the common law "rule of completeness, when part of an unrecorded oral statement or conversation, a writing, or a recorded statement is offered by one's opponent on direct examination, one may offer on cross-examination any other part that is necessary to put the first-admitted part in context, so that it will not be misleading.

The Rule provides for another alternative as to the timing of the admission of the additional, contextual evidence when part of a priting or recorded sertement his been proved: opposing counsel may ask the court to require the party who has introduced the First part of the wining or recorded statenent 20 introdace at that time any other part or any other writing or recorded statement whick ought in farrness to be considered contemporaneously with it."

The common law rule remains unchanged: the Rule is a complement to it.

\section{Chapter 200--Judicial Notice}

\section{JUDICIAL NOTICE OF ADJUDICATIVE FACTS}

Judicial notice of adjudicative facts: conclusive in civil cases, so that evidence may not be introduced to disprove a noticed fact. On the other hand, in criminal cases, the jury must be instructed that it may, but is not required to, accept as conclusive any judicially noticed fact adverse to the accused.

\section{Chapter 300-Presumptions in Civil Actions}

\section{PRESUMPTIONS IN CIVIL ACTIONS}

\section{(a) Effect}

Effect of rebuttable evidentiary presumptions (not mere permissible inferences and not just statements of who bears the ultimate burden of persuasion - which kind of presumption is involved is an important threshold question of law for the court, just as it is under current practice) in civil cases: codifies Grier v. Rosenberg, a middle ground betreen the strict "bursting bubble" approach and the Morgan approach of shifting-theultimate-burden of persuasion. The effect of the Rule is that the presumption shifts the burden of production of evidence to the opponent of the presumption. Depending on what evidence, if any, that party presents to disprove the presumed fact, the court may direct a finding for either party as to the existence or non-existence of the presumed fact (e.g., hay wagon case; parnership car case, Maryland Evidence $\$ 301.2 . c .7$ ) or it may send the issue to the jury for its resolurion (facts of Grier). 
The Rule is intended to give the court appropriate flexibility, so that a jury-question will remain if appropriate, and to facilitate the cour's avoiding having to direct a judgment against the party who enjoys the benefit of a presumption, simply because the opponent has offered self-serving testimony as to the non-existence of the presumed fact ( $\ddot{e} . \mathrm{g}$., "That was my chauffeur's day off. He was not authorized to drive the car.").

\section{(b) Inconsistent presumptions}

Tiebreaker when there are conflicting presimptions: the court shall apply the one that it determines is founded upon weightier considerations of policy and logic. If neither carries the day, both shall be ignored.

\section{APPLICABILITY OF PRESUMPTION OF ANOTHER JURISDICTION IN CIVIL ACTIONS}

Because the effect given to a presumption may determine the outcome in a case, if a Maryland court, under its conflicts of law principles, applies another jurisdiction's presumption, it shall give the presumption the same effect as it has in the other jurisdiction.

\section{Chapter 400--Relevancy and Its Limits}

DEFINITION OF "RELEVANT EVIDENCE"

Definition of "relevant evidence:" collapses common lat materiality and relevance into one term.

\section{RELEVANT EVIDENCE GENERALLY ADMISSIBLE; IRRELEVANT EVIDENCE ADMISSIBLE}

Irrelevant evidence is inadmissible; relevant evidence is admissible, unless otherwise provided. Exclusionary rules created by case law that is not inconsistent with the Rules in Title 5 are not implicitly overruled.

\subsection{EXCLUSION OF RELEVANT EVIDENCE ON GROUNDS OF PREJUDICE, CONFUSION, OR WASTE OF TIME}

The all-important clean-up batter: the Coun has discrerion to exclude relevant evidence if its probative value is substantially outweighed by the risk of unfair prejudice, confusion, or waste of time. This Rule applies even when evidence "may" (but not when it "shall") be admitted under a more specific Rule. 
5.404 CHARACTER EVIDENCE NOT ADMISSIBLE TO PROVE CONDUCT; EXCEPTIONS; OTHER CRIMES

(a) Character Evidence Generally

(1) In General

Character evidence is generally inadmissible to prove conduct in accordance with character: the propensity nule. Consistent with current Maryland law.

\section{(A) Character of Accused}

Exception applicable when an accused (iictuding a fuvenile alleged to be delinquent) offers evidence of his or her good character as ro perinent trait. Prosecution then may rebut with unfavorable character witnesses. (Permissible methods of proof opinion or reputation. See Rule 5-405(a)).

\section{(B) Character of Victim}

Exception applicable as to perinent trate of a vicion - in crimual cases only, the accused may offer unfavorable evidence of the victim's pertinent character trait (eg., violence); the prosecution then may offer favorable character evidence of the victim (or, in a homicide case only, to rebut evidence that the vietim was the first aggressor). (Methods of proof: opinion and reputation testimony. See Rule 5-405(a)).

\section{(C) Character of Witness}

Exception applicable to permit impeachment and rehabilitation of credibility of a witness who has testified at the trial or hearing by evidence regarding the witness's character for telling the truth. (See Rules 5-607, 5-608, and 5-609.)

\section{(2) Definitions}

The Rule treats a child alleged to be delinquent as an accused.

(b) Other Crimes, Wrongs, or Aas

Character evidence of other crimes, wrongs, or acts - which are proved by clear and convincing evidence - may be admitted for purposes other than proving "propensity," e.g., motive, intent. The Rule does not incorporate the notice requirement added to the Federal Rules of Evidence in 1991. Consistent with current Maryland law. 
(a) Reputation or Opinion

Opinion and reputation testimony are equally admissible on direct examination of character witnesses.

Those witnesses may be crossexamined about their knowledge of relevant specific instances of the principal witness's conduct. The Rule is consistent with former Maryland law, except that it precludes a character witness from tertifymg befort the gins to the specific acts that led the witness to form his of her opinion. (See also Rule 5-608(a)(3)(B).) Also, it broadens the communities from whidf $5-803(21))$.

(b) Specific Instances of Conduct

When character is an essential element of a charge, claim, or defense, under the substantive law, e.g., when negligent entrustment is alleged or when truth is raised as a defense to a defamation claim, character may be proved by evidence of specific acts, as well as by reputation or opinion testimony. Consistent with Maryland law.

Admissible evidence of an individual's specific habit or a business or other organization's routine practice, when offered to show that the individual or entity followed that practice on the occasion in question. Consistent with current Maryland law.

\subsection{SUBSEQUENT REMEDIAL MEASURES}

Evidence of subsequent remedial measures: the Rule follows the substance of the Federal Rule of Evidence and, unlike current Maryland case law, provides for no "standard of care" exception.

The Rules Committee had proposed the addition of a subsection to the Rule, addressing products liability cases. Remedial measures taken after a product is placed into the stream of commerce would have been protected by the proposed Rule. The Court left the issue of the Rule's application to products liability cases to development through the case law. 


\section{(a) (1)-(3)}

Evidence of compromise of a civil claim in dispute, offers to make such a compromise, or conduct or statements made in compromise negotiacions or mediation will be inadmissible to prove the validity, invalidity, or amount of the claim. The Rule goes beyond the current Maryland law by protecting starements made in mediation and in compromise negotiations, even though not phrased as hypotheticals or stated without prejudice."

(b) The Rule does not provide a means to shelter evidence also obtained outside compromised negotiations or mediation.

(c) The Rule precludes such statements from being used eithes as substantive evidence of the validity, invalidity, or amount of a court ciaim in dispute, or to impezch as a prior inconsistent statement. Like current Maryland law, however, it permits the use of such statements for other purposes, such as to show bias.

(d) The Rule extends the protection for compromise negotiatons in avil cases to protect against the use of those civil negotiations in related criminal actions, based on the same conduct. This is consistent with the federal case law. The Rule does not, however, protect effors to obstruct a criminal investigation or prosecurion. (See (c).)

The Rule changes existing Maryland law by precluding the admission of evidence of furnishing, offering, or promising to pay medical and similar expenses for an infured person, when offered to prove the offeror/payor's civil or criminal hiability for the injury, The Rule does not extend to offers to pay or payment of property damages. RELATED STATEMENTS

(2)(1) $-(4)$

General inadmissibility against the defendant who made the plea or was a participant in the plea discussions, of (1) guilty pleas, which were not accepted or were later withdrawa or vacated [this group does not include a guilty piea that is the subject of an appeal from the District Court to the Circuit Court (see (c))]; (2) nolo contendere pleas (exception: attorney grievance proceeding (see Rule BV 10 e 1 ); or (3)-(4) statements made during Rule 4243 or Rule 11 proceedings or during plea discussions with a prosecutor. 


\section{(b) Exceptions}

(1) First exception: starements made dunng plea discassions or Rule 4243-type proceedings may be admissible under the "rule of completeness" when znother statement made in the course of the same plea or plea discussions has been introduced.

(2) Second exception: statements made durng Rule 4243 type proceedings may be admissible as prior inconsistent statements, for impeachment purposes, in a subsequent civil procseding:

(3) Third exception: admissibility of ftarements made under oath and on the record, when the defendant is subsequently tried for perjury.

General inadmissibility of evidence of liability insurance; possible admissibility for limited purpose. Consistent with current Maryland law. BEHAVIOR

Maryland "rape shield" statute, incorporated by reference.

Chapter 600--Witnesses

General rule that, except as provided by law, all persons are competent to be witnesses.

The Committee note points out that a cour could find that a particular witness is not competent, because of insufficient memory or ability to express oneself or inability to appreciate the need to tell the truth.

\subsection{LACK OF PERSONAL KNOWLEDGE}

General requirement of first-hand knowledge, with exceptions as to (1) the witness's own date of birth and other matters of personal history (see Committee note) and (2) experts (see Rule 5-703). 
Requirement of oath or affirmation in some form, to impress the witness with the duty to tell the truth.

\section{5-604 INTERPRETERS}

Interpreters: qualification as experts and requirement of oath or affirmation.

5-605 COMPETENCY OF JUDGE AS WITNESS

Presiding judge may not testify. Point is preserped for appeal even without objection.

\subsection{COMPETENCY OF JUROR AS WITNESS}

(a) At the trial

Jurors may not testify as witnesses before the jury.

(b)-(c) Inquiry Into Validity of Verdict

Neither petit jurors' testimony nor their statements may be used in inquiries into the validity of their verdicts or of sentences returned by them, as to (A) any matter or statement occurring during jury deliberations; (B) the effect of anything upon a juror's mind or emotions; or (C) the juror's mental processes in connection with the verdict $A$ Committee note explains that the Rule does not address or affect the secrecy of grand jury proceedings.

Rule 1-501, eliminating the common law voucher rule, so that one may impeach one's own witness, is moved here. A Committee note explains that the Spence, $321 \mathrm{Md}$. 526 (1991), limitation remains.

5.608

EVIDENCE OF CHARACTER OF WITNESS FOR TRUTHFULNESS OR UNTRUTHFULNESS

(a) Impeachment and Rehabilitation by Character Witnesses

(1) Impeachment by a Character Witness

Unfavorable opinion or reputation testimony as to another witness's character trait for truthfulness. 
(2) Rehabilitation by a Character Witness

Favorable opinion or reputation testimony as to an impeached witness's character trait for truthfulness, when the method of impeachment constitutes an attack on the wirness's character for truthfulness.

(3) Limitations on Character Witness's Testimony

(A) A character witness may nor grve an opimion is to whetfier the other witness testified truefifully.

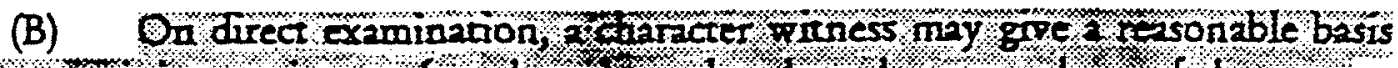
for reputation or opinion restimony (eg, how 1 ong they have been members of the same community or how long they have known ad (tother) but nay not teriff to specific instances of the other viness's truthfulness or untrutbfitilness.

\section{(4) Impeachment of a Character Witness}

A character witness who has given either favorable or unfavorable opinion or reputation testimony on direct examination as to another witness's character for truthfuiness, may be impeached on cross-examination by being asked abour the other wimess's prior specific acts, including prior convictions, which would lead to the opposite opinion or reputation.

Upon objection, a showing must be made both that (1) a reasonable factual basis exists for asserting that the prior act occurred, and (2) the act is relevant to the other witness's reputarion or to the character witness's opinion.

Rule 5-608(a) is consistent with current Maryland law, except that under the Rule: (1) a character witness may not testify to an opinion as to whether the principal witness testified truthfully; (2) on direct, a character witness may not testify to specific acts of truthfulness or untruthfulness by the principal witness (see also supra Rule 5-405); and (3) on cross of a character witness, specific instances may be inquired into - on objection only if a foundation is laid, including a reasonable factual basis for asserting that the prior instances occurred.

(b) Impeachment by Examination Regarding Witness's Own Prior Conduct not Resulting in Conviations

Impeachment, in the court's discretion, by prior bad acts not having resulted in conviction: consistent with current Maryland law, except for a caveat like that listed in 5608(a)(4) above, i.e., upon objection, a showing must be made outside the hearing of the jury that a reasonable factual basis exists for asserting that the witness committed the prior act. 


\section{(c) Effect on Privilege Against Self-Incrimination}

Privilege against self-incrimination is not waived by witnesses as to matters relating only to credibility, such as contemplated in 5-608(b) above.

-5.609 IMPEACHMENT BY EVIDENCE OF CONVICTION OF CRIME

Impeachment by prior convietion: current Rule 1-502:

(a) Generally

To be admissible, prior convictions either of infamous crimes or of other crimes relevant to credibility must pass a balancing test: their probative value outweighs the danger of unfair prejudice. See Beales, 329 Md. 263 (1993); Giddens, 97 Md. App. 582 (1993), cert. granted.

\section{(b) Time Limit}

Bright line of 15 years since the date of conviction.

\section{(c) Other Limitations}

Inadmissible if on appeal; if time period for appeal has not expired; if the witness has been pardoned; or if the conviction has been reversed or vacated.

\section{(d) Effect of Plea of Nolo Contendere}

Nolo pleas followed by a sentence (even a suspended sentence) are convictions for purposes of Rule 5-609.

\section{5-610 RELIGIOUS BELIEFS OR OPINIONS}

Witnesses' religious beliefs generally inadmissible to enhance or impair credibility, except when probative of bias.

5.611 MODE AND ORDER OF INTERROGATION AND

PRESENTATION: CONTROL BY COURT; SCOPE OF CROSSEXAMINATION; LEADING QUESTIONS

\section{(a) Control by Court}

Reasonable control by cour of mode and order of questioning witnesses and presenting evidence, in the interests of truth, efficiency, and protecting witnesses from harassment or undue embarassment. 


\section{(b) Scope of Cross-examination}

Consistent with current Maryland law: limited cross, ith counts discretion to permit exceeding scope of direct, but with nonteading questions. Exception. criminal defendants who testify on non-preliminary matters are subject to wide-open cross.

\section{(c) Leading questions}

The Rule is generally consistent with former Maryland practice, but a bit broader than the relevant statute, in that the Rule generally permins leading on directeof pitnesses "identified with" an adverse party. See, eg., Perkins v. Volkswagen of America, Inc., 596 F.2d 681 (5th Cir. 1979) (dictum concerning employee of party opponent).

\section{$5-612$}

\section{WRITING OR OTHER ITEM USED TO REFRESH MEMORY}

Present memory refreshed while the witness is testifying: other parties may inspect and introduce into evidence relevant parts of the refreshing item, for impeachment only.

(a) Examining Witness Concerning Prior Statement

Questioning a witness about his or her prior statement: the Rule takes the middleof-the-road between Queen Caroline's Rule and the federal rale. The Rulte does not require counsel to disclose the witness's prior statement to the wituess before questioning the witness about it, but does require counsel to disclose it and give the witnes an opportunity to explain or deny it before the end of counsel's examination of the witness.

(b) Extrinsic Evidence of Prior Inconsistent Statement of Witness

Genesally, extrinsic evidence of the witness's prior inconsistent statement will be permitted only if 5-613(a) has been followed, the witness bas failed to admit having made the statement, and the statement concerns a non-collateral matter. The interests of justice might "otherwise require" as to impeachment of a non-testifying hearsay declarant.

\section{5-614 CALLING AND INTERROGATION OF WITNESS BY COURT}

\section{(a) Calling bv Court}

Witnesses may be called by the cour (parties must be given reasonable opportunity to object outside jury's presence). All parties may crossexamine. 
(b) Interrogation by Court

Questioning of witnesses by the court. Codifies Maryland case law.

\section{5-615 EXCLUSION OF WITNESSES}
(a) In General
(b) Witnesses Not to be Excluded
(d) Nondisclosure
(e) Exclusion of Testimony

Sequestration of witnesses: generally consistent with former Rules 2-513, 3-513, and 4321 (which are delered by conforming amendments), Code, art. 27, $\ 620$, and Maryland case law.

\section{(c) Permissive Non-Exclusion}

Subsection (c) of the Rule empowers the court in its discretion to permit a support person to remain in the courtroom during a child's testimony.

\section{IMPEACHMENT AND REHABILITATION-GENERALLY}

The Rule summarizes for the convenience of counsel and the courts, the rules concerning impeachment and rehabilitation of the credibility of a witness, and provides cross-references as applicable. Except as noted above as to specific preceding Rules, the Rule codifies Maryland case law:

(a) Impeachment by Inquirv of the Witness

The Rule catalogues - but does not limit - permissible methods of impeaching a witness.

(b) Extrinsic Impeaching Evidence

The Rule catalogues the occasions when extrinsic impeaching evidence may be admitted, including the McCormick test as to collateral matters.

(c) Rehabilitation

The Rule catalogues - but does not limit - permissible methods of rehabilitation of a wirness whose credibility has been atracked.

The Rule conditions the admissibility of prior consistent statements on their being logically rebutting of the impeachment that had occurred. 
Chapter 700-0pinions and Expert Testimony

5.701 OPINION TESTIMONY BY LAY WITNESSES

Lay opinions: consistent with Maryland case law. TESTIMONY BY EXPERTS

Admissibility of expert testimony: consistent with Maryland case law.

The FryeReed v. Daubent issue as to the sandard for admissibility of novel scientific evidence is unaddressed by the Rule and is left to development through the cose law.

$5 \cdot 703$

\section{BASES OF OPINION TESTIMONY BY EXPERTS}

(a) In General

Permissible bases of expert opinion. Consistent with Maryland case law.

(b) Disclosure to Jury

Cour's discretion to permit disclosure to the jury of a substantively inadmissible basis for an admissible opinion. Limiting instruction avilable on request. Consistent with Maryland case law.

(c) Right to Challenge Exper

The Rule does not limit an opponent's right to test the basis of an expert's opinion. Consistent with Maryland case law.

5.704 OPINION ON ULTIMATE ISSUE

(a) In General

Opinions are not inadmissible merely on the ground that they embrace ultimate issues in the case. Consistent with Maryland case law.

(b) Opinion on Mental State or Condition

Expert opinion may be given as to an ultimate issue of an accised's criminal responsibility, but not as to whether the defendant had a required intent or mental state constituting an element of the crime charged. Consistent with Maryland case law. 
Changes current Maryland law by permitting - unless the court requires otherwise- an exper to testify to his or ber opinion without first testifying to the facts or data on which it is based.

5-706 COURT-APPOINTED EXPERTS

Court-appointed expers: a detailed proposil, e.8. permilting any part, to depose 2 court-appointed witness.

(a) Appointment

In the court's discretion, on court's own initiative or on motion of a party.

(b) Compensation parties.

Funds which may be provided by law. In most civil actions, charged as costs to the

(c) Disclosure of Appointment

Disclosure to the jury, in the court's discretion, that the witness is court-appointed.

(d) Paries' Experss of Own Selection

Not limited by Rule $5-706$.

\section{Chapter 800 -. Hearsay}

\subsection{DEFINITIONS}

Definition of hearsay: the Rule follows the federal rule. It rejects the common law rule, insofar as it extended to implied assertions from nonverbal, nonassertive conduct of the type addressed in dictum in the classic English case, Wright v. Doe dem. Tatham. The extent to which implied assertions from verbal utterances are defined as hearsay is left to development through the case law.

\section{(a) Statement}

Either (1) an oral or written assertion or (2) nonverbal conduct intended as an assertion, i.c., engaged in with a communicative purpose, as the equivalent of particular words. 
(b) Declarant

Person who makes 2 statement.

(c) Hearsar

A statement, other than one made by the declarant while testifying at the trial or hearing, offered in evidence to prove the truth of the matter asserted.

A Committee note explains that what constitutes an assertion is left to development in the case $\mathrm{l}_{2 \mathrm{w}}$, but the fact that an utrerance F. for example, in the form of 2 question would not necessanly preclude its being an zssction.

Hearsay is inadmissible, except as otherwise provided by rule, statute, or constitution.

Here the Rules deviate from the organization of the Federal Rules of Evidence, which include no Rule 802.1. The Committee found Fed. R. Evid. 801 internally contradictory, in that it establishes a definition of hearsay in $801(\mathrm{c})$ and then provides in $801(\mathrm{~d})(1)(\mathrm{A}) \cdot(\mathrm{C})$ and (2) that four categories of statements, all of which meet that definition, are not hearsay.

The Committee opted to put admissions of party opponents in Rule 5-803, with the other hearsay exceptions as to which it does not matter whether the declarant testifies or is available to testify.

The Committee noted that the other three of those categories in Fed. R. Evid. $801(d)$ all require that the declarant testify at the trial or hearing and be subject to crossexamination concerning the statement. The only other hearsay exception to contain the requirement that the declarant testify at trial was past recollection recorded, which is codified in Federal Rule of Evidence 803(5). Thus, as had been done similarly in Hawaii, the Committee combined that hearsay exception with those from Fed. R. Evid. 801(d), and a Maryland exception for prompt complaint of rape and other sexual assault into a new Rule 5.802.1.

The hearsay exceptions set forth in Rule 5-802.1 permit substantive use of the following categories of prior statements by a declarant who testifies at trial and is subject to cross-examination concerning the statement: 
(a) Prior inconsistent statements)

A statement that is inconsistent with the declarant's testimony, if the seatement was eirher:

(1) Given under oath subject to the penalty of perjury at a tral, hearing or other proceeding [thus including a proceeding before a grand jurf] or in a deposition; ot

(2) reduced to writing and signed by the declaznt; or

(3) recorded in substantially verbation fashion by stenographic or Aectronic means contemporaneously with the making of the szatement. See Nance v. State, 331 Md. 549 (1993); Hawail R. Evid. 802.1(c).

\section{(b) (Prior consistent statements)}

A witness's prior consistent statements, offered to rebut an implied or express charge of fabrication or improper influence or motive. Consistent with Maryland case law.

(c) (Prior identification)

Prior statements of identification of a person made after perceiving the person. Consistent with Maryland case law.

(d) Prompt complaint of sexual assault

Prompt complaints of rape and other sexual assaults. The Maryland cases are criminal and most concern rape. The Rule is extended to other sexual assaults, whenever relevant, i.e, including civil cases.

(e) (Past recollection recorded)

The hearsay exception for past recollection recorded codifies Maryland case law, except that the Rule provides that the written statement may be read into evidence but may nor irself be received as an exhibit unless offered by an adverse party. A Commirtee note states that a writing that is not received as an exhibit should be marked for identification.

\section{HEARSAY EXCEPTIONS: UNAVAILABILITY OF DECLARANT} NOT REQUIRED

Hearsay exceptions applicable, regardless whether the declarant is available as a witness or testifies or not: 


\section{(a) Statement by Party.Opponent}

Statements of party-opponent ("admissions of a party opponent"), including:

(1) The party's own statement;

(2) Adoptive admissions, including tacit admissions;

(3) Authorized statements;

(4) Statements "by the party's agent or employee made during the agency or employment relationship concerning a matter within the scope of the agency or employment" (same rule ss zoopted in BER Rentuls \& Sales Co. $v$. Universal Leaf Tobacco Co., 324 Md. 147 (1991));

(5) Statements "by a co-conspirator of the party during and in furtherance of the conspiracy."

A Commitree note makes clear that, where there is a disputed issue as to a foundational requirement, eg., scope of employment, or the existence of a conspiracy, the cour must make a finding on that issue before the statement may be admitted. Whether the court may "bootstrap" by considering the starement irself in making that determination is left to development through the case law. Compare, e.g., Daugherty v. Kessler, 264 Md. 281 (1972) with Bourjaily v. United States, 483 U.S. 171 (1987).

(b) Other Exceptions

(1) Present Sense Impressions

Codifies Maryland case law.

(2) Excited Utterances

Codifies Maryland case law.

(3) Then Existing Mental, Emotional, or Physical Condition

"State of mind" (consistent with Maryland case law, but not admissible to prove what someone other than the declarant did after the statement was made). Statement of present physical condition (consistent with Maryland case law). 
(4) Statements for Purposes of Medical Diagnosis or Treatment

Statements made for purposes of medical treatment or medical diagnosis in contemplation of trearment. Consistent with Maryland case law.

(5) Recorded Recollection

[Past recollection recorded is addressed in Rule 5-802.1(e).]

(6) Records of Regularly Conducted Business Activity $902(a)(11)$

"Business records" exception. As to selfeuthentication of certified copies, see Rule

(7) Absence of Entry in Records Kept in Accordance with Subsection (b)(6)

Absence of entry in business record, offered to prove that the event did not occur.

(8) Public Records and Reports

Public records and reports (this Rule not to override more specific statutes). The Rule does not mandate following the broader reading of "factual findings" found in Beech Aircrafi Corp. v. Rainey, 488 U.S. 153 (1988) than was adopted in Ellsworth v. Sheme Lingerie, Inc., $303 \mathrm{Md} .581$ (1985).

(9) Records of Vital Statistics

Records of vital statistics, except as otherwise provided by statute, e.g., Md. HealthGen. Code Ann. $\$$ 5-311 (medical examiner's records).

$$
\text { Absence of Public Record or Entry }
$$

Unless the circumstances indicate a lack of trustworthiness, absence of public record or entry (certificate of the custodian will suffice).

$$
\text { Records of Religious Organizations }
$$

Statements of personal or family history, contained in regularly kept records of religious organization.

(12) Marriage, Baptismal, and Similar Certificates

To prove the marriage or other ceremony. 
(13) Family Records

Family records concerning personal or family history.

(14) Records of Documents Affecting an Interest in Property

Public office's records of documents affecting an interest in property, as proof of the content of the original recorded document and its execution and delivery by each person by whom it purpors to have been executed.

$$
\text { Statements in Documents Affecting an Interest in Property }
$$

Unless circumstances indicate a lack of trustworthiness.

$$
\text { Statements in Ancient Documents }
$$

"Ancient documents": statements in authenucaced documents (see Rüle 5-901(b)(8)) that are at least 20 years old, unless circumstances indicate 2 lack of trustwarthiness.

\section{Market Reports and Published Compilations}

Market quotations, lists, and other published compilations, generally used and reasonably relied upon by the public or by persons in parcicular occupations.

\section{Leamed Treatises}

On direct or cross of an expert witness, statements in leamed treatises, when the treatises bave been establisbed as reliable by (1) the testimony or admission of the witness, (2) other expert testimony, or (3) judicial notice. Treatises may be read into evidence bur may not be received as exhibits.

$$
\text { Reputation Conceming Personal or Family History }
$$

Reputation, prior to the controversy before the court, concerning personal or family histor:

(22) Reputation Concoming Boundaries or General History

(A) Reputation, prior to the controversy before the court, as to boundaries of, interests in, or customs affecting lands.

(B) Reputation as to historical events imporant to the community, state, or nation where they occurred. 
Reputation of a person's character "among associates or in the community."

[Vacant]

\author{
Judgment as to Personal, Family, or General History, or Boundaries
}

Judgments as proof of facts of family history, general history, or land boundaries, i.e., the types of facts addressed in exceptions (19) and (20) above, essential to the judgments.

\title{
Other Exceptions
}

The "carch-all" hearsay exception. The Rule provides:

Under exceptional circumstances, the following are not excluded by the hearsay rule, even though the deciarant is available as a witsess: A ratement not specifically. covered by any of the foregoing exceptions but having equivalens circumsantial gursontes of trustworthiness, if the court derermines that $(A)$ the statement is offered as exiderice of 2 maserial fiet; $(B)$ the stateme: is more probative on the poins for which it is offered thian any other evidence which the proponent can procure through reasonable efforts; and (C) the geseral purposes of these rales and the interess of justice will best be served by admission of the statement into evidence. A ratement may not be admitted under this exception unless the proponent of it makes known to the adverse party, sufficiently in advance of the trial or hearing to provide the adverse part: with a fair opportunity to prepare to meet it, the intention to offer the satement and the particulars of it. including the name and address of the declarant.

Commitree note: The residual exceprions provided by Rule 5-803 (b)(24) and Rule $5-804$ (b)(5) do not contemplate an unietresed exercise of judicial diseretion, but they do provide for trearing aex and presently unanticipated siruasions which demonstrate a inustzonhiness wirhin the spint of the specifically sated exceptions. Within this framer.ork, room is lefr for growth and development of the las. of evidence in the hearsay area, consistently with the broad purposes expressed in Rule 5-102.

It is intended that the residual hearsay exceptions will be used very rarely, and only in exceptional erscumsances. The Committee does not intend to establish a broad license for trial judges to admit hearsay statements that do not fall within one of the orher exceptions contained in Rules 5-803 and 5-804 (b). The residual exceptions are not meant to authorize major judicial revisions of the hearay rule, including its present exceptions. Such major revisions are best accomplished by amendments to the Rule itself. It is intended that in any case in which evidence is sought to be admited under these subsections, the trial judge a.ill exercise no less care, reflection, and caution than the courts did under the common lax in establishing the now-recognized exceptions to the hearsay rule. 

testify:

Hearsay exceptions applicable only when the declarant is shown to be unavailable to

(a) Definition of Unavailability

Unavailability includes situations in which the declarant:

(1) is exempted from testifying by the court's ruling that a privilege applies;

(2) refuses to testify, despite a court order to do so;

(3) testifies to a lack of memory of the subject matter (trial judge, under Rule 5-104(a), would determine whether lack of memory existed);

(4) is unable to be present or to testify because of death or physical or mental illness or infirmity;

(5) the proponent of the statement offered under subsection (b) has been unable to procure the declarant's attendance for, if the evidence is offered under the hearsay exceptions for dying declararions, declarations against interest, or statements of personal or family history, has been unable to obtain the declarant's attendance or testimony) by process or other reasonable means.

The Rule is, unlike the current Maryland Rules regarding the admission of deposition testimony, equally strict in civil and criminal cases 25 to what lengths a party must go to obtain the trial testimony of a witness. The Rule requires process and, where process is not an option, "otber reasonable means."

(b) Hearsav: Exceptions

(1) Former Testimony

Prior testimony in any action or proceeding, or deposition testimony taken in any scrion or proceeding, where the party against whom the testimony is now offered (or, in a civil action, the parry's predecessor in interest) had a similar motive to develop the testimony (regardless whether on direct or cross). 


\section{(2) Statement Under Belief of Impending Death}

Dying declarations: broadened to permit thesr admission in prosecurions for an unlawful homicide, attempted homicide, or assault with intent to cammit a homicide commited against the now unavailable (through not necessarily dead) declarant and in any civil action.

\section{(3) Statement Against Interest}

Declaration against (pecuniary, proprietary, or penal) interest (corroborating circumstances required for admission of another's statement against penal interest that is offered to exculpate the accused).

(4) Statement of Personal or Family History

Declarant is now unavailable. Exception is slightly broader than Maryland case law.

(5) Other Exceptions

The "catch-all" exception applicable when the declarant is unavailable. Otherwise, identical to Rule 5-803(b)(24).

$$
\text { HEARSAY WITHIN HEARSAY }
$$

Multiple hearsay.

(a) In General

Impeachment and rehabilitation of a hearsay declarant. The Rule permits proof of a nontestifying declarant's prior inconsistent statement.

\section{(b) Exception}

Admissions of statements of a pary opponent, whether in the form of the party's orin statement or an adoptive admission, does not open the party up to impeachment. Thus, the State cannot, by offering an accused's out-of-court statement, open the door to its impeachment of a nontestifying accused. 


\section{Chapter 900 -Authentication and Identification}

(a) General Provision

Generally, the admission of evidence is conditioned on preliminary evidence of authentication sufficient to support a finding by the trier of fact that the evidence in question is what its proponent claims it to be. See Rule 5-104(b).

(b) Illustrations

Non-limiting illustrations of methods of authentication:

(1) Testimony of Witness With Knowledge

Testimony of a witness with personal knowledge (including "chain of custody" evidence, but existing statutes are unaffected).

(2) Non-Expert Opinion on Handwriting

Lay opinion on handwriting.

(3) Comparison with Authenticated Specimens

Comparison by the court or an expert witness of, e.g., hair, fingerprints, handariting, with items that have been authenticated (no special hurdles for handwriting exemplars).

(4) Circumstantial Evidence

E.g. note found on dead body; reply telephone call.

(5) Voice identification

Wirness need not have been familiar with the voice before the event in question.

(6) Telephone Conversation

Outgoing telephone calls. 
(7) Public Records

Public records (but certified copies are self-authenticating, see Rule 5-902(a)(4); see also 5-902(a)(1)-(3)).

(8) Ancient Document or Data Compilation

"Ancient (20 years old or more) documents (that don't look suspicious).

(9) Process or System

Underlying process or system produces an accurate result, e.g., X-rays, computergenerated exhibits.

(10) Methods Provided by Statute or Rule

Merhods provided by statute or rule remain.

\section{SELF-AUTHENTICATION}

(a) Generallv

Self-authenticating items (no evidence of authentication required as condition precedent to admissibility as what proponent claims them to be - unless otherwise provided by statute; of course, opponent remains free to offer evidence of inauthenticity):

(1) Domestic Public Docummts Under Seal

(2) Domestic Public Documcrits Nor Under Seal

Signed by officer, etc., ahose signature is certified (see (b)).

(3) Forcign Public Docummts

Officially executed or attested. and, generally, accompanied by a final certification (defined in (b)).

(4) Centified Copics of Public Records

See (b).

(5) Official Publications

Publications purporting to be issued or authorized by a public agency. 
(6) Newspapers and Periodicals

(7) Trade Inscriptions and the Like

Trade inscriptions, labels, etc.

(8) Acknowledged Documents

Documents acknowledged by notary, etc.

(9) Commercial Paper and Related Documents

As provided by applicable commercial law.

(10) Presumptions under Statutes or Treaties

Matters declared by statute or treaty to be presumptively authentic.

(11) Certified Records of Regularly Conducted Business Activity

Certified copies or orginals of foreign or domestic business records, tracking foundation requirements of hearsay exception $5.803(\mathrm{~b})(6)$, requirements of advance notice and opportunity to inspect. Cf. Rules $2-510(\mathrm{~g})$ and $3-510(\mathrm{~g})$ (hospital records); 18 U.S.C. S 3505. See (b).

(12) Items as to Which Required Objections Not Made

Unless justice otherwise requires, iterns as to which pretrial objections are required by statute, rule, or court order.

(b) Definition

Rule.

Definition of "certifies," "certificate," or "certification." Derived from Uniform

\subsection{SUBSCRIBING WITNESS TESTIMONY UNNECESSARY}

Testimony of a subscribing witness is not required to authenticate a writing, unless otherwise provided by statute.

$5 \cdot 1001$

\section{DEFINITIONS}

Definitions applicable to the "best evidence rule." Consistent with current Maryland law. 
Requirement of original writing, recording, or photograph to prove the content thereof, except as otherwise provided by rule (see especially 5-1003) or statute. Consistent with current Maryland law.

\section{$5 \cdot 1003$}

\section{ADMISSIBILITY OF DUPLICATES}

Duplicates (including photocopies) are equally admissible as originals, unless it would be unfair to admit the duplicate or a genuine question is raised as to the authenticity of the original. Consistent with current Maryland law.

\section{ADMISSIBILITY OF OTHER EVIDENCE OF CONTENTS}

Evidence other than the original may be used if, (a)-(c), the original is lost, destroyed, unobrainable by reasonably available process or procedure, or in the possession of one's opponent, or (d) the writing, recording, or photograph is not closely relared to a controlling issue in the case. The Rule dispenses with the common law "pecking order" of secondary evidence.

5-1005

PUBLIC RECORDS

Proof of contents of public records by cerrified copy, by testimony of a person who has compared a copy with the original, or, if neither type of copy can be obtained through reasonable diligence, by other evidence.

SUMMARIES

Summaries of voluminous writings, etc., that are otherwise admissible. Requirements of notice and opportunity to inspect and copy. Consistent with current Maryland law.

$5 \cdot 1007$ TESTIMONY OR WRITTEN ADMISSION OF PARTY

Proof of contents of a.ritings, etc. by testimony or written admission of opposing party.

$5-1008$ FUNCTIONS OF COURT AND JURY

Division of labor between judge and jury, with regard to application of the "best evidence rule." 